\title{
EFFECTS OF PHOTOSELECTIVE SHADE NETS ON EARLY GROWTH OF SUGARCANE SEEDLINGS
}

\author{
José J. F. Cordeiro Júnior ${ }^{*}$, Sávio D. L. Cavalcanti², Rayanne T. de A. Souza ${ }^{2}$, \\ Pedro H. D. Batista ${ }^{2}$, Cristiane Guiselini ${ }^{2}$
}

${ }^{1 *}$ Corresponding author. Federal University of Sergipe / Nossa Senhora da Glória - SE, Brasil.

E-mail: jairofcordeiro@hotmail.com | ORCID ID: http://orcid.org/0000-0002-1138-8309

\section{KEYWORDS}

protected environment, shade nets, solar radiation, Saccharum officinarum.

\begin{abstract}
Sugarcane has a great economic interest in Brazil, so it needs technologies to increase its yield strength, especially for seedling production. This study aimed to ascertain the influence of shading nets on early growth and development of pre-sprouted sugarcane seedlings. An experiment was conducted in a protected environment, in the Rural Federal University of Pernambuco (UFRPE), in Recife-PE, Brazil. The protected environments were covered with anti-UV low-density polyethylene plastic plus: Solpack ${ }^{\circledR}$ red ultranet net, Solpack ${ }^{\circledR}$ white net, Solpack ${ }^{\circledR}$ freshnet net, and without shade net, and five replications each. The experiment was carried out in a completely randomized design, and multivariate principal component analysis (PCA) was used to verify associations among cultivation modules, micrometeorological factors, and seedling growth parameters. AntiUV low-density polyethylene + shade net improved seedling growth and development up to 27 days after planting. Higher substrate temperatures benefited early growth of seedlings. After 27 days of planting, sugarcane seedlings required higher air temperatures, as well as increased global and photosynthetically active solar radiation.
\end{abstract}

\section{INTRODUCTION}

Brazil is the world's largest sugarcane producer and export leader, responsible for over $50 \%$ of its derivatives that are traded around the world, mainly sugar and ethanol. Due to this, the search for new cultivation technologies has increased to provide greater profitability and production quality (Nascimento et al., 2015).

Pre-sprouted seedling (PSS) production is an alternative to conventional planting, which leads to an excessive number of stems and spread of diseases. PSS is a technology that allows greater control of seedling quality, vigor, and soundness (Xavier et al., 2016).

It is therefore of crucial importance to know the practices used from harvesting and propagative material storage to field transplanting of seedlings. About seedling growth, plants require certain shade conditions during the initial period of production to favor their development (Lee et al., 2007).

As micrometeorological conditions exert great influence on sugarcane seedling viability, photoselective shade nets enable changes in the environment that may influence sprouting and seedling growth (Cordeiro Júnior et al., 2019; Gama et al., 2017; Hirata \& Hirata. 2015; Masabni et al., 2016). This has great importance since changes in solar radiation, photosynthetically active radiation, relative air humidity, soil and air temperatures can benefit or hinder seedling growth (Cantu et al., 2013; Klein et al., 2016; Silva et al., 2013).

Given the above, this study aimed to investigate the influence of shade nets on early growth and development of pre-sprouted sugarcane seedlings.

\section{MATERIAL AND METHODS}

The study was conducted between September and October 2016, in the campus of the Rural Federal University of Pernambuco (UFRPE), in Recife - PE, Brazil ( $8^{\circ} 04^{\prime} 03^{\prime \prime}$ $\mathrm{S}$ and $\left.34^{\circ} 55^{\prime} 00^{\prime \prime} \mathrm{W}\right)$. According to Köppen's classification, the climate is megathermal (As'), with a mean annual temperature of $25.2^{\circ} \mathrm{C}$ (Pereira et al., 2002).

The protected environment consisted of an arched greenhouse, covered by low-density polyethylene (LDPE) with anti-UV additive, $50 \%$ shade net on the sides, and the following dimensions: 21-m length, 7-m width, 3-m ceiling height, $4.5-\mathrm{m}$ total height, and $147-\mathrm{m}^{2}$ total area.

\footnotetext{
${ }^{2}$ Universidade Federal Rural de Pernambuco/ Recife - PE, Brasil.
} 
Seedlings were obtained from a pre-sprouted seedling (PSS) system, using a method adapted from Xavier et al. (2016). While these authors used three distinct environments for sprouting, early growth, and development of seedlings, we opted for a single environment.

Modifications consisted of planting mini-setts of sugarcane in 15-cell trays, conducting sprouting and seedling growth in the same protected environment, under shade nets. Five trays were used per plot, totaling 20 plots and 100 trays for sugarcane seedling production, using sugarcane cultivar RB92579 and coconut powder as substrate.

Seedling production was carried out under a subirrigation system equipped with a cultivation platform. It was composed of a water tank, a submerged pump, and an analog timer. The timer was set to turn the pump on at 7 am daily, pumping nutrient solution for $15 \mathrm{~min}$ to the highest part of the platform. This way the solution would rise through the substrate by capillarity until it reached the root system.

The protected environment was divided into four modules: 1) anti-UV LDPE + Solpack $^{\circledR} 35 \%$-shade red ultranet net (anti-UV LDPE + red ultranet), 2) anti-UV LDPE + Solpack ${ }^{\circledR} 50 \%$-shade white net (anti-UV LDPE + white), 3) anti-UV LDPE + Solpack $^{\circledR} 50 \%$-shade freshnet thermo-reflective net (anti-UV LDPE + freshnet), and 4) anti-UV LDPE without shade net (anti-UV LDPE). Up to 12 days after planting (DAP), the nets were placed at 0.15 $\mathrm{m}$ above the ground, and then raised to $1 \mathrm{~m}$ for the following 28 days (from 13 to 40 DAP).

Energy availability was characterized in each environment and outdoors, using sensors. These enabled continuous micrometeorological measurements of global solar radiation (GSR; CMP3 Pyranometer LI200/R sensor; $400-1100 \mathrm{~nm}$ ) and photosynthetically active radiation (PAR; LI190SB Quantum sensor; 400-700 nm). These

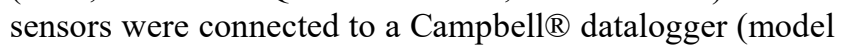
CR1000) for data acquisition. Then, the relationship between GSR and PAR was determined and expressed as PAR\% for each crop module.

Substrate temperature (Tsubs, ${ }^{\circ} \mathrm{C}$ ), air temperature (Tair, ${ }^{\circ} \mathrm{C}$ ), and relative air humidity $(\mathrm{RH}, \%)$ were recorded in each cultivation module using HOBOware ${ }^{\circledR}$ minidataloggers. The sensors were installed at the geometric center of the cultivation modules, i.e., half-length, halfwidth, and $1.5 \mathrm{~m}$ above the ground. Measurements were taken daily at one-second intervals, with averages of 15 -min intervals, until seedlings were ready for transplantation.

Non-destructive analyses were performed from 13 to 19 DAP, from 20 to 26 DAP, from 27 to $33 \mathrm{DAP}$, and from 34 to $40 \mathrm{DAP}$, when the following seedling biometric variables were recorded:

Leaf area (LA) was determined by counting green leaf number and measuring them +3 . Leaves were measured lengthwise and crosswise in the middle portion, according to Hermann \& Câmara (1999), and area determined as shown in the [eq. (1)]:

$$
\mathrm{LA}=\mathrm{L} \times \mathrm{W} \times 0.75 \times(\mathrm{N}+2)
$$

Where:

$$
\begin{aligned}
& \mathrm{L}=\text { leaf length }+3 ; \\
& \mathrm{W}=\text { leaf width }+3, \\
& \mathrm{~N}=\text { number of open leaves with more than } 20 \% \\
& \text { green area. }
\end{aligned}
$$

Leaf area index (LAI, $\mathrm{m}^{2} \mathrm{~m}^{-2}$ ) was estimated as the relationship between leaf area and plant area, as shown in [eq. (2)]:

$$
\mathrm{LAI}=\frac{\mathrm{NT} \cdot \mathrm{LA}}{\mathrm{S}}
$$

Where:

$\mathrm{NT}=$ number of tillers per $\mathrm{m}^{2}$;

$\mathrm{LA}=$ leaf area per tiller $\left(\mathrm{m}^{2}\right)$,

$\mathrm{S}=$ area occupied by the plant $\left(\mathrm{m}^{2}\right)$.

Plant stem diameter (SD, mm) was measured using a digital caliper.

Stem length (SL, mm) was measured with the aid of a graduated ruler.

Plant height $(\mathrm{PH}, \mathrm{cm})$ was accounted for by direct measurement of 10 plants using a graduated ruler.

Absolute growth rate in plant height (AGRph) was calculated as in [eq. (3)] (Paulino et al., 2011), which estimates seedling growth rate (in $\left.\mathrm{cm} \mathrm{day}^{-1}\right)$ :

$$
\text { AGRph }=\left(H_{2-} H_{1}\right) / t_{2} t_{1}
$$

Where:

$$
\begin{aligned}
& \mathrm{H}_{1}=\text { average height at time } 1(\mathrm{~cm}) ; \\
& \mathrm{H}_{2}=\text { average height at time } 2(\mathrm{~cm}), \\
& \mathrm{t}_{2}-\mathrm{t}_{1}=\text { time interval between measures (days). }
\end{aligned}
$$

Absolute growth rate in stem diameter (AGRsd) was calculated as in [eq. (4)] (Paulino et al., 2011) (in cm day ${ }^{-1}$ ):

$$
\text { AGRsd }=D_{1}-D_{2} / t_{1} t_{2}
$$

Where:

$$
\begin{aligned}
& D_{1}=\text { stem diameter at time } 1(\mathrm{~cm}) ; \\
& D_{2}=\text { stem diameter at time } 2(\mathrm{~cm}), \\
& \mathrm{t}_{2}-\mathrm{t}_{1}=\text { time interval between measures (days). }
\end{aligned}
$$

Absolute growth rate in fresh weight (AGRfw) was calculated as in [eq. (5)] (Paulino et al., 2011), which estimates phytosystem size increase (in $\mathrm{cm}^{3} \mathrm{day}^{-1}$ ):

$$
\text { AGRfw }=\left(\mathrm{H}_{2} \mathrm{D}_{2}{ }^{2}-\mathrm{H}_{1} \mathrm{D}_{1}{ }^{2}\right) / \mathrm{t}_{1}-\mathrm{t}_{2}
$$

Where:

$$
\begin{aligned}
& \mathrm{H}_{1}=\text { average height at time } 1(\mathrm{~cm}) ; \\
& \mathrm{H}_{2}=\text { average height at time } 2(\mathrm{~cm}) ; \\
& \mathrm{D}_{1}=\text { average stem diameter at time } 1(\mathrm{~cm}) ; \\
& \mathrm{D}_{2}=\text { average stem diameter at time } 2(\mathrm{~cm}), \\
& \mathrm{t}_{2}-\mathrm{t}_{1}=\text { time interval between measures (days). }
\end{aligned}
$$

The experiment was carried out in a completely randomized design with four variation factors (anti-UV LDPE + red net; anti-UV LDPE + white net; anti-UV LDPE + freshnet; anti-UV LDPE solely) and five replications, totaling 20 plots. Each plot consisted of 75 seedlings, totaling 1,500 sugarcane seedlings. 
Effects of photoselective nets were evaluated for global solar radiation (GSR), photosynthetically active radiation (PAR), air temperature (Tair), relative air humidity (RH), substrate temperature (Tsubs), and solar radiation spectrum.

Associations among cultivation modules, micrometeorological factors, and plant sprouting were evaluated by multivariate principal component analysis (PCA), based on the correlation matrix of variables. Before PCA, data were standardized given the large variation and order of magnitude of variables.

\section{RESULTS AND DISCUSSION}

According to the data covariance matrix, the first and second principal components (PCs) explained above $67.5 \%$ of the total variation in the four studied periods. This implies that data variability and associations among parameters can be described in only two main axes.

Anti-UV LDPE + shade net showed greater association with plant biometric parameters than those covered with anti-UV LDPE solely. It can be observed by their similar location in graphs for modules (Figure 1A) and variables (Figure 1B). Moreover, it can be confirmed due to negative correlation of GSR, PAR, and Tair with plant height $(\mathrm{r}=-0.68,-0.73$, and -0.41 , respectively) and stem length ( $\mathrm{r}=-0.89,-0.92$, and -0.66 , respectively). Photoselective shade nets helped attenuate micrometeorological hazards and reduce extreme changes in the protected environments, which are unfavorable to seedling growth, thus allowing maintenance of growth factors within suitable ranges during early seedling development (Guiselini et al., 2013; Ferrari \& Leal, 2015).

During early development, the higher the GSR, PAR, and Tair, the lower the sugarcane seedling growth. Between 13 and 19 DAP (Growth), seedlings were sensitive to micrometeorological elements such as Tair, GSR, and RH (Figure 1B). Thus, during early growth, shading is crucial in protected environments for sugarcane seedling production against high temperature and solar radiation intensity (Almeida Neto, 2019; Guiselini et al., 2013; Silva et al., 2019).
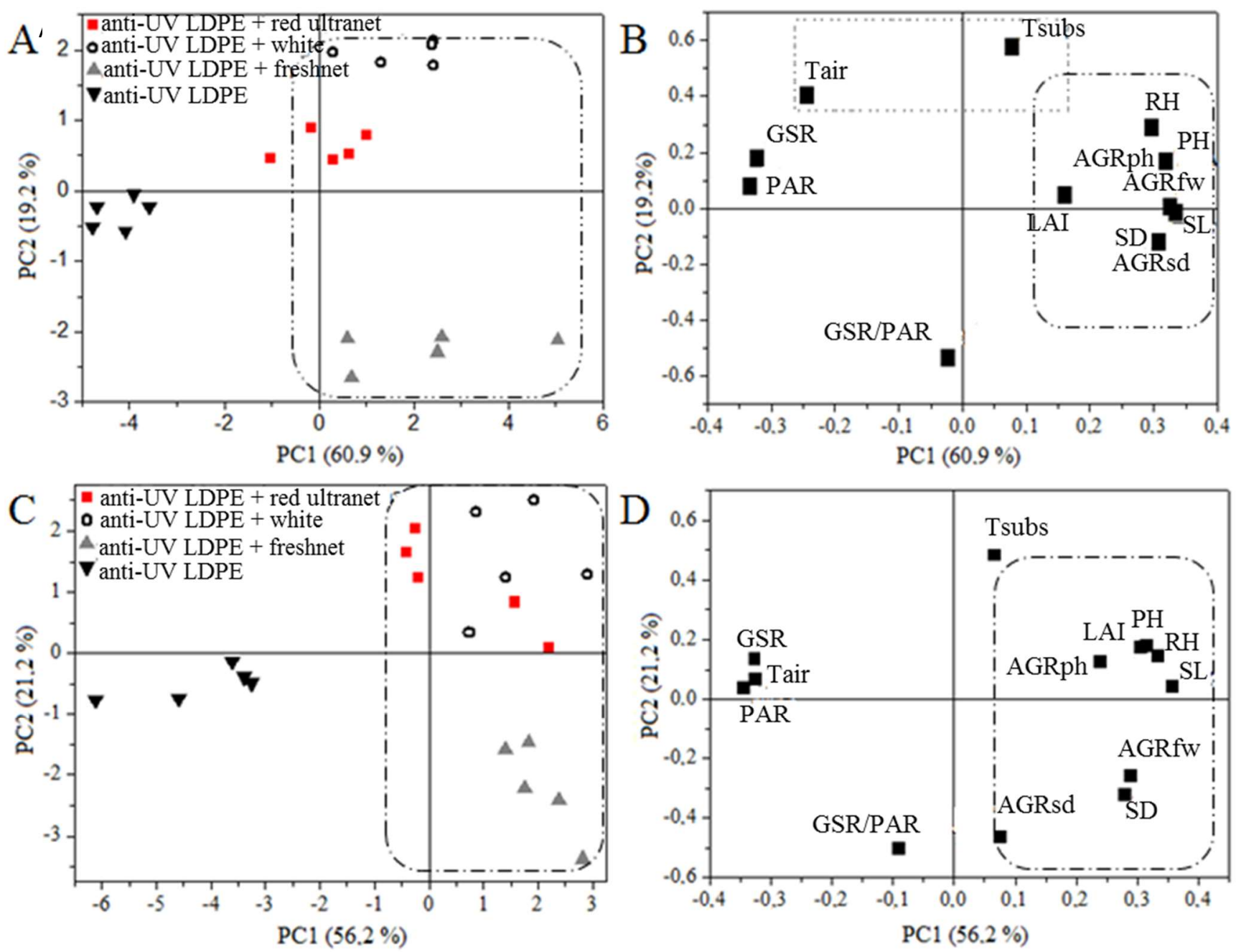

FIGURE 1. Score graphs of principal component 1 (PC1) vs. principal component 2 (PC2) for modules (A) for variables (B) for modules from 13 to 19 DAP (C) and variables (D) from 20 to 26 DAP. Plant height (PH), stem length (SL), stem diameter (SD), leaf area index (LAI), absolute growth rate in fresh weight (AGRfw), absolute growth rate in stem diameter (AGRsd), absolute growth rate in plant height (AGRph), substrate temperature (Tsubs), air temperature (Tair), air relative humidity (RH), global solar radiation (GSR), photosynthetically active radiation (PAR), relationship between GSR and PAR (GSR/PAR). Recife, Brazil, 2018. 
Air relative humidity $(\mathrm{RH})$ was positively correlated with biometric parameters, including plant height $(\mathrm{PH})(\mathrm{r}=$ $0.77)$ and stem length $(\mathrm{SL})(\mathrm{r}=0.82)$. Substrate temperature (Tsubs) was more correlated with PH $(r=0.40)$, SL $(r=$ $0.25)$ and leaf area index (LAI) $(r=0.20)$ (Figure 1B). Silva et al. (2004) observed satisfactory growth of pre-sprouted sugarcane seedlings at $80 \%$ RH. Xavier et al. (2016) reported greater initial development of sugarcane PSS at $90 \%$ RH, i.e., the closer to $90 \% \mathrm{RH}$, the greater the seedling development.

Net shading increased associations between cultivation modules and biometric measures. It can be seen by their similar location in graphs for modules (Figure 1C) and variables (Figure 1D). Anti-UV LDPE + red ultranet and anti-UV LDPE + white showed a higher association with LAI, PH, SL, and AGR. This may be related to larger Tsubs and RH accumulated in these modules.

Anti-UV LDPE + freshnet was more associated with AGRfw, SD, and AGRsd (Figure 1D). This module presented a lower association with GSR, Tair, PAR, and had a mean Tair of $29.4{ }^{\circ} \mathrm{C}$, which is the lowest among the studied modules. Therefore, micrometeorological components were more attenuated in this module. Freshnet nets have thermo-reflective properties, thus increasing GSR reflection and Tair alleviation (Araújo et al., 2016).

Both RH and Tsubs were positively correlated with biometric measures, among them $\mathrm{PH}(\mathrm{r}=0.72$ and $\mathrm{r}=0.31$, respectively) and SL ( $r=0.90$ and $r=0.21$, respectively) (Figure 1D). Yet, Tair was negatively correlated with SD ( $r$ $=-0.70)$, that is, the higher the Tair, the lower the SD. Guerra et al. (2014) observed that a Tair range between 29 and $23{ }^{\circ} \mathrm{C}$ increased SD of sugarcane seedlings.

From 27 to 33 DAP, white and freshnet shade nets had a greater association with $\mathrm{RH}$ and GSR/PAR ratio, as well as with PH, SL, SD, AGRph and AGRfw (Figure 2A and 2B). Moreover, during this period, sugarcane seedlings started to accumulate AGRsd and LAI in modules with anti-UV LDPE + red ultranet and anti-UV LDPE solely. Such change might be related to the development stage of sugarcane metabolism, as $\mathrm{C} 4$ plants are better adapted to light and drought stress (Kluge et al., 2014; Martinez et al., 2015).

Figure 2B shows a negative correlation between Tsubs and biometric parameters, in other words, the higher the Tsubs, the smaller the seedling development after 27 DAP. LAI was positively correlated with GSR $(\mathrm{r}=0.28)$, $\operatorname{PAR}(\mathrm{r}=0.27)$ and Tair $(\mathrm{r}=0.30)$. This shows that, from 27 DAP onward, sugarcane seedlings required a greater intensity of GSR, PAR, and Tair to promote an increase in leaf area. Brunini \& Turco et al. (2016) reported that smaller leaf areas end up harming plant development by reducing solar radiation interception, thereby affecting physiological processes and hence final production.
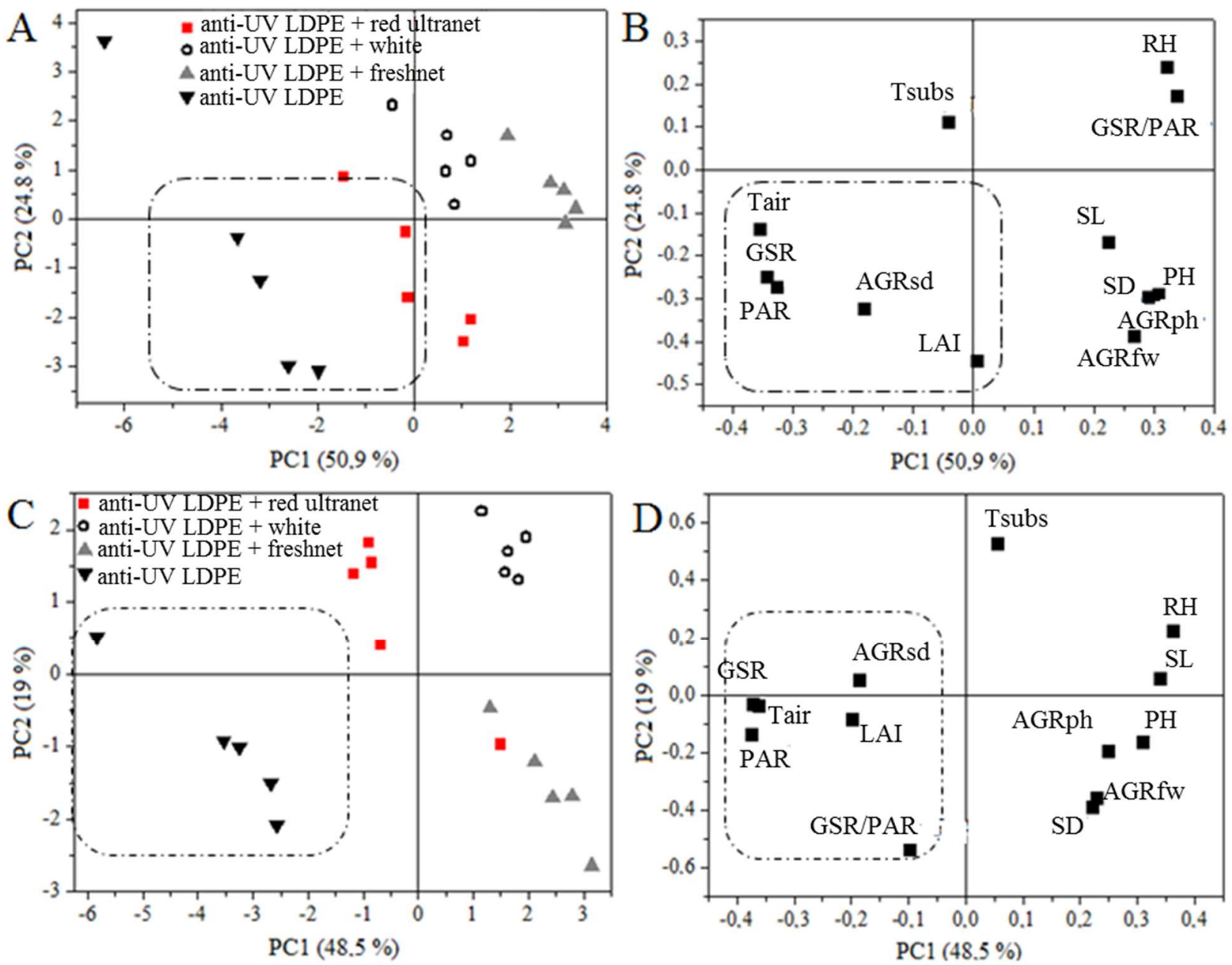

FIGURE 2. Score graphs of principal component 1 (PC1) vs. principal component 2 (PC2) for modules (A; objects) and variables (B; weights) from 27 to 33 DAP and for modules (C) and variables (D) from 34 to 40 DAP. Plant height (PH), stem length (SL), stem diameter (SD), leaf area index (LAI), absolute growth rate in fresh weight (AGRfw), absolute growth rate in stem diameter (AGRsd), absolute growth rate in plant height (AGRph), substrate temperature (Tsubs), air temperature (Tair), air relative humidity (RH), global solar radiation (GSR), photosynthetically active radiation (PAR), relationship between GSR and PAR (GSR/PAR). Recife, Brazil, 2018. 
Figure $2 \mathrm{C}$ shows a greater association between antiUV LDPE + white net with Tsubs, RH, and SL. In turn, SL had greater correlation with Tsubs $(\mathrm{r}=0.23)$ and $\mathrm{RH}(\mathrm{r}=$ $0.73)$, but negative with GSR $(r=-0.68)$ and PAR $(r=-$ 0.73). Higher Tsubs and RH averages in the cultivation environment provided higher SL of sugarcane PSS since a satisfactory growth of these seedlings occurs at an RH of $80 \%$ (Silva et al., 2004).

In anti-UV LDPE + white and anti-UV LDPE + freshnet modules, GSR and PAR transmittances into the environment were lower. This promoted higher SL and $\mathrm{PH}$ in seedlings under 50\% shade net (Figure 2C and 2D). It might have occurred as an adaptive mechanism to speed up plant growth under shaded conditions (Moraes-Neto et al., 2000).

Lastly, anti-UV LDPE-covered module had a greater association with GSR, PAR, and Tair (Figure 2D), as well as with AGRsd and LAI. This confirms the behavior started at 27 DAP, since which seedlings required more GSR, PAR, and Tair to increase LAI $(\mathrm{r}=0.68,0.63$, and 0.56 , respectively) and AGRsd $(\mathrm{r}=0.29,0.33$, and 0.42, respectively). Guiselini et al. (2013) reported that sugarcane seedlings had an increased LAI under greater availability of GSR (37.66 $\mathrm{MJ} \mathrm{m}^{-2}$ week $\left.^{-1}\right)$ in the growing environment. Physiological changes have also been observed when GSR and PAR rates were reduced in sugarcane plants (Elli et al., 2016).

\section{CONCLUSIONS}

Until 27 days after planting, anti-UV low-density polyethylene + shade net improved growth and development of pre-sprouted sugarcane seedlings;

From 27 days after planting onward, anti-UV lowdensity polyethylene + shade net inhibited growth and development of pre-sprouted sugarcane seedlings;

Higher substrate temperatures benefited early growth of sugarcane seedlings;

From 27 days after planting onward, sugarcane seedlings required more global solar radiation, photosynthetically active radiation, and air temperature.

\section{ACKNOWLEDGEMENTS}

To Solpack ${ }^{\circledR}$ Ltda for availability and supply of the photoselective shade nets tested in this survey.

\section{REFERENCES}

Almeida Neto LA, Pandorfi H, Moraes AS, GUISELINI C, Cordeiro Júnior JJF (2019) Biophotonics: acclimation of pre-sprouted sugarcane seedlings in protected environment. Engenharia Agrícola 39(4):410-418. DOI: https://dx.doi.org/10.1590/1809-4430-

eng.agric.v39n4p410-418/2019
Araújo HF de, Leal PAM, Zorzeto TQ, Betin PS, Nunes EF, Servilha GFP (2016) Alterações micrometeorológicas em ambientes protegidos cultivados com minitomate orgânico. Irriga 21(2):226-238. DOI: https://doi.org/10.15809/irriga.2016v21n2p226-238

Brunini RG, Turco JEP (2016) Crescimento da cana-deaçúcar (Sacharum ssp L.) em diferentes cenários produtivos de exposições e declividades. Ambiência 12(3):841-849. DOI:

http://dx.doi.org/10.5935/ambiencia.2016.Especial.09

Cantu RR, Goto R, Junglaus RW, Gonzatto R, Cunha AR (2013) Uso de malhas pigmentadas e mulching em túneis para cultivo de rúcula: efeito no ambiente e nas plantas modelo. Ciência Rural 43(5):810-815. DOI: http://dx.doi.org/10.1590/S0103-84782013005000048

Cordeiro Júnior JJF, Pandorfi H, Barbosa Filho JAD, Moraes AS, Almeida Neto LA de, Guiselini C (2019) Photo-selective shade nets on the production and quality of sugarcane plantlets. Revista Brasileira de Engenharia Agrícola e Ambiental 23(5):366-371. DOI: https://dx.doi.org/10.1590/18071929/agriambi.v23n5p366-371

Elli EF, Caron BO, Paula GM de, Eloy E, Schwerz F, Schmidt D (2016) Ecofisiologia da cana-de-açúcar no subbosque de Peltophorum dubium Spr. em sistemas de sistemas agroflorestais. Comunicata Scientiae 7(4):464472. DOI: https://doi.org/10.14295/cs.v7i4.1538

Ferrari DL, Leal PAM (2015) Use of thermoreflective screens on greenhouses for tomato production. Engenharia Agrícola 35(2):180-191. DOI:

http://dx.doi.org/10.1590/1809-4430-

Eng.Agric.v35n2p180-191/2015

Gama DRDS, Mesquita AC, Yuri JE, Ferreira KM, Souza V (2017) Different shading environments impact growth and yield of three mini-tomato cultivars. Revista Caatinga 30(2):324-334. DOI: http://dx.doi.org/10.1590/1983$21252017 \mathrm{v} 30 \mathrm{n} 207 \mathrm{rc}$

Guerra A, Barbosa ADM, Guidorizzi KA, Souza GM (2014) Efeitos da temperatura do ar na fotossíntese da cana-de-açúcar na fase inicial do desenvolvimento. Revista Agrarian 7(24):211-217. DOI: 10.30612/agrarian.v7i24.2565

Guiselini C, Pandorfi H, Barros ACB, Silva LF, Silva Neto SPO (2013) Aclimatização de mudas de cana-de-açúcar em ambiente protegido sob dois tipos de malhas de sombreamento. Revista Brasileira de Engenharia Agrícola e Ambiental 17(8):877-882. DOI:

http://dx.doi.org/10.1590/S1415-43662013000800012

Hirata ACS, Hirata EK (2015) Desempenho produtivo do agrião d'água cultivado em solo sob telas de sombreamento. Pesquisa agropecuária brasileira 50(10):895-901. DOI: http://dx.doi.org/10.1590/S0100204X2015001000005 
Hermann ER, Câmara GMS (1999) Um método simples para estimar a área foliar de cana-de-açúcar. Revista da STAB 17(1):32-34.

Klein J, Rampim L, Kestring D, Guimarães VF, Rodrigues JD (2016) Influência de protetores físicos coloridos nas trocas gasosas em mudas de canafístula [Peltophorum dubium (Spreng.) Taub.]. Ciência Florestal 26(3):797-809. DOI: http://dx.doi.org/10.5902/1980509824208

Kluge RA, Tezotto-Uliana JV \& Da Silva PP (2014) Aspectos fisiológicos e ambientais da fotossíntese. Revista Virtual de Química 7(1):56-73. DOI: https://doi.org/10.5935/1984-6835.20150004

Lee TSG, Bressan EA, Silva ADC da, Lee LL (2007) Implantação de biofábrica de cana-de-açúcar: riscos e sucessos. Revista Brasileira de Horticultura Ornamental 13(1):2032-2040. DOI: https://doi.org/10.14295/oh.v13i0.1960

Masabni J, Sun Y, Niu G, Del Valle P (2016) Shade Effect on Growth and Productivity of Tomato and Chili Pepper. HortTechnology 26(3):344-350. DOI: https://doi.org/10.21273/HORTTECH.26.3.344

Martinez CA, Oliveira EAD, Mello TRP, Alzate-Marin AL (2015) Respostas das plantas ao incremento atmosférico de dióxido de carbono e da temperatura. Revista Brasileira de Geografia Física 8(8):635-650.

Moraes-Neto SP, Gonçalves JLM, Takaki M, Cenci S, Gonçalves JC (2000) Crescimento de mudas de algumas espécies arbóreas que ocorrem na mata atlântica, em função do nível de luminosidade. Revista Árvore 24(1):35-45.
Nascimento MRR do, Rodrigues WOP, Schlindwein MM (2015) Reflexos do setor canavieiro para o crescimento econômico da microrregião de dourados em Mato Grosso do Sul. Organizações Rurais \& Agroindustriais 17(2):149-162.

Paulino J, Folegatti MV, Flumignan DL, Zolin CA, Barboza Júnior CRA, Piedade SM de S (2011)

Crescimento e qualidade de mudas de pinhão-manso produzidas em ambiente protegido. Revista Brasileira de Engenharia Agrícola e Ambiental 15(1):37-46. DOI: https://dx.doi.org/10.1590/S1415-43662011000100006

Pereira AR, Angelocci LR, Sentelhas PC (2002) Agrometeorologia: fundamentos e aplicações práticas. Guaíba, Agropecuária, 478p.

Silva CR, Vasconcelos CS, Silva VJ, Sousa LB, Sanches MC (2013) Crescimento de mudas de tomateiro com diferentes telas de sombreamento. Bioscience Journal 29(5):1415-1420.

Silva MA, Carlin SD, Perecin D (2004) Fatores que afetam a brotação inicial da cana-de-açúcar. Revista Ceres 51(296):457-466.

Silva RP, Torres BA, Souza JL, Souza PHV, Monquero PA (2019) Uso de herbicidas no controle de plantas daninhas e em mudas pré-brotadas (MBPS) de diferentes variedades de cana-de-açúcar. Revista Brasileira de Herbicidas 18(1):640-1. DOI: https://doi.org/10.7824/rbh.v18i1.640

Xavier MA, Landell MGA, Mendonca JR, Rossato JR JAS, Silva PH, Morelli RRG, Petri RH, Pizzo IV (2016) Capacitação em produção de Mudas Pré-Brotadas (MPB) e taxa de multiplicação de cana-de-açúcar. STAB 35:40. 